\title{
The Pathological Role of Pro(Renin) Receptor in Renal Inflammation
}

This article was published in the following Dove Press journal:

Journal of Experimental Pharmacology

\author{
Syed S Quadri' \\ Caleb Cooper ${ }^{2}$ \\ Dawood Ghaffar' \\ Hitesh Vaishnav' \\ Ludmila Nahar ${ }^{3}$ \\ 'DeBusk College of Osteopathic Medicine, \\ Lincoln Memorial University, Knoxville, \\ TN, USA; ${ }^{2}$ DeBusk College of Osteopathic \\ Medicine, Lincoln Memorial University, \\ Harrogate, TN, USA; ${ }^{3}$ Department of \\ Medicine, School of Medicine/John \\ D. Bower School of Population Health, \\ University of Mississippi Medical Center, \\ Jackson, MS, USA
}

\begin{abstract}
Pro)renin receptor (PRR) is the recently discovered component of the reninangiotensin-aldosterone system (RAS). Many organs contain their own RAS, wherein PRR can exert organ-specific localized effects. The Binding of prorenin/renin to PRR activates angiotensin-dependent and independent pathways which leads to the development of physiological and pathological effects. Continued progress in PRR research suggests that the upregulation of PRR contributes to the development of hypertension, glomerular injury, and progression of kidney disease and inflammation. In the current review, we highlight the function of the PRR in renal inflammation in pathophysiological conditions.
\end{abstract}

Keywords: prorenin receptor, renal inflammation, hypertension, diabetes, renin-angiotensin system

\section{Introduction}

Renin and prorenin were thought of as proenzymes, but recent evidence suggests that they also could act as hormones as they bind to cellular targets and mediates physiological actions. ${ }^{1,2}$ Binding of renin/prorenin to PRR has been shown to increase the catalytic activity of renin by about four- to fivefold and induce a signaltransduction cascade leading to vasoconstriction, sodium, and water reabsorption, cell growth, proliferation, and inflammatory responses. ${ }^{3-5}$ It is expressed in almost all of the body tissues including smooth muscle, kidney, liver, brain, testis, lung, heart, and adipose tissue, ${ }^{3,6,7}$ and activation of PRR has been linked to upregulation and activation of mitogen-activated protein kinases (MAPKs) and extracellular signal-regulated kinases (ERK). ${ }^{8}$

\section{Expression/Signaling of (Pro)Renin Receptor (PRR) in the Kidney}

(Pro)renin receptor (PRR), a new member of the renin-angiotensin system (RAS) encoded by ATPase $\mathrm{H}(+)$-transporting lysosomal accessory protein 2 (ATP6AP2) was first cloned in mesangial cells. ${ }^{2}$ Full length PRR is a 350 -amino acid protein (Figure 1) with a single transmembrane domain consists of four different domains namely, N-terminal signal peptide, a large extracellular domain, a signal transmembrane domain, and a short cytosolic domain. ${ }^{7}$ The extracellular domain can be cleaved to soluble PRR (sPRR) which is secreted into the blood and urine. ${ }^{9}$ Binding of sPRR to prorenin leads to the generation of angiotensin II (Ang II) and mediating the effects of renin/prorenin. ${ }^{10,11}$ The cytoplasmic domain complexed with $\mathrm{V}$-ATPase is involved in lysosomal acidification ${ }^{12}$ and is independent of prorenin/
Correspondence: Syed S Quadri

DeBusk College of Osteopathic Medicine, Lincoln Memorial University, 9737 Cogdill

Road, Knoxville, TN, 37932, USA

Tel + I 865 338-5724

Email syed.quadri@Imunet.edu
Journal of Experimental Pharmacology 2021:13 339-344 

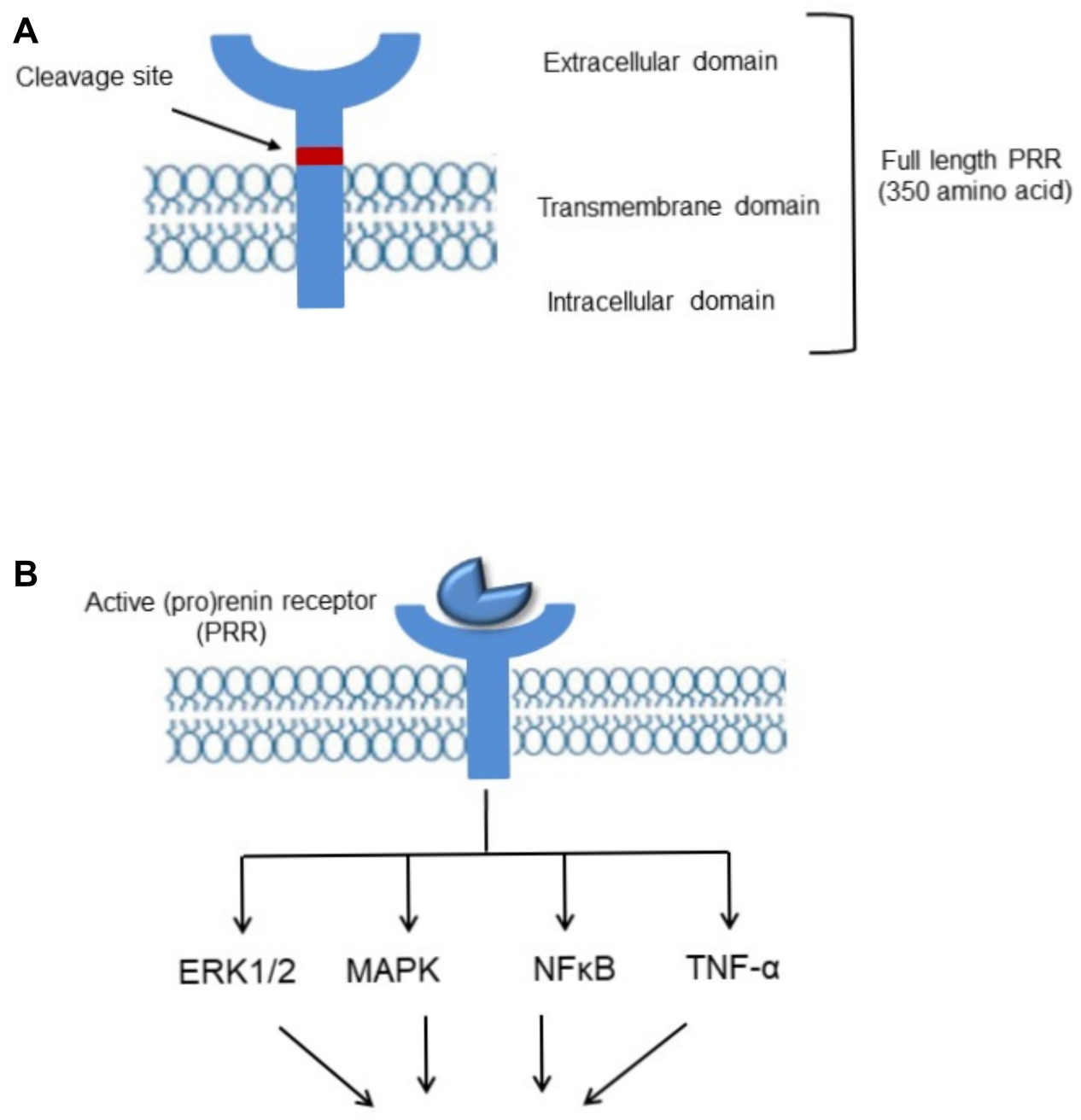

Fibrosis/ Inflammation

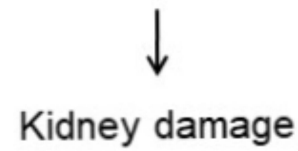

Figure I (A) Biology and signaling of (pro)renin receptor. Representative schematic organization. (B) (Pro)renin receptor (PRR) signaling pathways. Activation/upregulation of PRR induces kidney damage via ERKI/2, MAPK, NF-кB, TNF- $\alpha$ pathway.

renin binding to $\mathrm{PRR}^{13}$ (Figure 1). Recent studies reported that PRR acts as an adaptor protein between the Wnt receptor and V-ATPase complex, resulting in activation of the Wnt- $\beta$-catenin signaling pathway which regulates physiologic embryonic development and also pathological disease $^{14,15}$ and deletion of PRR during embryogenesis caused pronounced proteinuria, renal failure, and death. ${ }^{16,17}$

In the kidney, PRR is mainly expressed in podocytes, mesangial cells, proximal and distal renal tubules. ${ }^{2,7,18}$ Depending on the form of PRR, actions can be either Ang II-dependent or independent. Activation of full length
PRR and soluble PRR (sPRR) mediates angiotensinogen cleavage, binds and activates prorenin/renin, and contributes to its Ras-dependent effects. ${ }^{19,20}$ Independent of Ang II, PRR activates mitogen-activated protein kinase (MAPK)-extracellular signal-regulated kinase (ERK) $)^{21-23}$ signaling pathway which induces proliferation and activation of inflammatory and fibrotic molecules including transforming growth factor $\beta$ (TGF- $\beta$ ), plasminogen activator inhibitor-1 (PAI-1), IL-1 $\beta$, nuclear factor-кB (NFкВ) and COX-2, contributing to kidney dysfunction. ${ }^{24}$

PRR is involved in Ang II production and intracellular signaling. Activation and overexpression of PRR in 
podocytes ${ }^{18}$ contribute to the slow progressive glomerular sclerosis, increases cell albumin permeability, and autophagy causing structural and functional abnormalities. . $^{16,18,25}$ Activation of ERK1/2 and PI3K-AKT signaling pathway by PRR plays a significant role in autophagosome development, induction of cell apoptosis, and organ damage. ${ }^{26}$ PRR contribution in Ang II generation and RAS activation is a significant step in kidney damage. ${ }^{27}$ In Goldblatt's hypertensive model PRR is increased in the clipped kidney, leading to Ang II formation in distal nephron segments, distal tubular sodium reabsorption, inflammation, and development of hypertension. ${ }^{6}$ A novel pharmacological inhibitor of PRR successfully attenuated the RAS-mediated increase in blood pressure. ${ }^{28,29}$ PRR knockdown in the salt-sensitive hypertension model also decreases Ang II formation. ${ }^{30}$

\section{Role of PRR in Renal Dysfunction and Inflammation}

The kidneys play a crucial role in regulating blood pressure, and salt and water balance. The PRR in the distal nephron is particularly of interest due to its role in stimulating sodium reabsorption and the development of hypertension. ${ }^{31}$ The impact of PRR on the kidney is evident from the fact that the expression of PRR is increased in different hypertensive models ${ }^{6,32}$ and the administration of PRR antagonists attenuated the hypertensive response and renal damage. ${ }^{28}$

PRR contributes to renal inflammation and fibrosis is a gradual process involving the RAS system in the development of hypertension and end-stage kidney damage. ${ }^{6,33}$ Hypertension damages the glomerular filtration barrier, which interferes with the filtration of circulating angiotensinogen, prorenin, renin, angiotensin I, and Ang II and their uptake in the proximal tubules. Recent evidence indicates that uptake of major components of the circulating RAS, including prorenin, may contribute to high levels of RAS proteins in the kidney. In the glomerulus, PRR is involved in the stimulation of tyrosine phosphorylation, leading to activation of the mitogen-activated protein kinase (MAPK) ${ }^{2}$ and subsequent increase in the expression of p-ERK, p-38, and p-JNK. ${ }^{34}$ PRR is also credited to increase the expression of transforming growth factor- $\beta$ (TGF- $\beta$ ) which was inhibited by blocking the prorenin receptor suggesting an independent role of PRR in renal damage. ${ }^{35,36}$ In the Goldblatt 2-Kidney 1-clipped hypertensive model, we found that PRR expression is upregulated in the clipped kidney and activates the MAPK/
ERK1/2 signaling pathway which in turn increased the expression of COX-2, NF-кB, and production of the inflammatory factors IL- $1 \beta$, tumor necrosis factor $-\alpha$ (TNF- $\alpha$ ), and monocyte chemoattractant protein-1 (MCP1). Targeted knockdown of PRR in the clipped kidney attenuated the expression of IL- $1 \beta$, TNF- $\alpha$, COX-2, and NF-кB indicating the intricate and direct interaction between PRR and renal inflammation. ${ }^{5}$

PRR also plays an important role in is renal dysfunction associated with diabetes. Diabetic nephropathy is characterized by increased renal inflammation and fibrosis and is strongly associated with glomerular injury leading to the development of the end-stage renal disease. ${ }^{37}$ The pathophysiology of diabetic nephropathy involves multiple mechanisms including the RAS dependent ${ }^{38}$ and independent mechanisms. ${ }^{39}$ Inflammatory cytokines, including IL1 , IL-6, and IL-18, and TNF- $\alpha$, are potentially involved in the development and progression of diabetic nephropathy. In vivo and human, studies confirm the role of RAS in the development and progression of kidney disease in diabetes. $^{40,41}$ Studies have shown that the expression of PRR was significantly increased in the invivo and invitro diabetic models ${ }^{18,42}$ along with the upregulation of oxidative stress. ${ }^{43}$ The expression and activity of prorenin and PRR are significantly increased in the diabetic kidney ${ }^{44}$ and together contribute to the fibrosis, cellular inflammation, proliferation, and apoptosis, and progression of diabetic nephropathy. ${ }^{24,39,45}$ These claims are supported by the research that shows that blockade of PRR in vivo reduced albuminuria and renal production of the inflammatory cytokines TNF- $\alpha$ and IL- $1 \beta^{39}$ and attenuated the development and progression of diabetic nephropathy. ${ }^{46-48}$ These changes were independent of changes in renal production of Ang II suggesting an independent and additive contribution of PRR in the development of renal inflammation in diabetes.

Upregulation of PRR expression in the kidney has been demonstrated in the streptozotocin-induced diabetic model where it augments the expression of inflammatory cytokines including TNF- $\alpha$ and interleukins, ${ }^{39}$ which activates second messenger systems, transcription factors, growth factors resulting in significant renal damage in diabetes. ${ }^{49}$ PRR mediated upregulation of cytokines also has been shown to induce apoptosis and alterations in endothelial permeability contributing to renal damage. ${ }^{50,51}$ The upregulation of PRR in diabetes also affects the structure and function of podocytes as evident with the reduction in podocin and nephrin through the Wnt3a- $\beta$-catenin-snail signaling 
pathway. ${ }^{18}$ Concurrent studies also showed that the PRR and cytokines prevent the formation of F-actin fibers resulting in the restructuring of the intercellular junction causing the loss of endothelial permeability, leading to podocytes injury. ${ }^{52,53}$ Down-regulation of PRR attenuated the inflammation and improves the F-actin expression and reorganization, ${ }^{18,24,26}$ indicating the direct role of PRR in the pathophysiology of diabetic kidney disease.

\section{Role of Soluble PRR (sPRR) in Renal Dysfunction and Inflammation}

Full length PRR can be cleaved to a soluble form of PRR (sPRR). The sPRR can either be retained inside cells and/ or secreted into plasma, urine, and extracellular space. $^{32,54}$ Evidence from the literature suggests that the upregulation of $\mathrm{SPRR}$ reflects the activation of RAS and direct stimulation of MAPK/ERK1/2 signaling pathway which may lead to renal dysfunction. ${ }^{32,55}$ Recent studies have identified a more specific role of SPRR in renal dysfunction which is demonstrated by the fact that SPRR activates the aquaporin 2 (AQP-2) channel in the distal nephron via frizzled- 8 and $\beta$-catenin signaling pathway and increases water reabsorption. ${ }^{11,56}$ Another study highlighted the role of sPRR in sodium reabsorption where sPRR upregulates epithelial sodium channel $(\mathrm{ENaC})$ in the distal nephron and increases sodium reabsorption. ${ }^{57}$ These findings indicate the role of sPRR in sodium and water homeostasis and the development of subsequent renal dysfunction. ${ }^{58}$ sPRR also promotes inflammation, adhesion, and endothelial dysfunction via NOX-4/NF$\kappa \mathrm{B}$ signaling pathway and increases the expression of cytokines including IL-6, IL-8, vascular cell adhesion protein 1 (VCAM-1), and Intercellular Adhesion Molecule 1 (ICAM-1). ${ }^{59}$ These inflammatory processes are gradual and may involve the RAS system. ${ }^{60}$ Significance of sPRR in renal fibrosis is demonstrated by Xie et al where sPRR is shown upregulates fibronectin in human renal proximal tubular cells via activation of AKT/ $\beta$-catenin/snail signaling pathway and inhibition of sPRR by selective S1P inhibitor PF429242 attenuated expression of fibronectin indicating an important role and identifying sPRR as a novel therapeutic target in renal fibrosis. ${ }^{61}$ In addition to the renal effects, sPRR plays a role in the impairment of the sympathetic nervous system and vascular tone. ${ }^{9,62}$ In obese mice induced with sPRR, blood pressure was increased due to elevation of leptin and sympathetic activation. ${ }^{63}$ In obesity-related hypertension sPRR has shown to impair the morphology of adipose tissue contributing to the inflammatory process. ${ }^{9}$ These effects were attenuated by knockdown of PRR suggesting that plasma leptin mediates the sPRR effect on sympathetic tone. 9,64 These mechanisms may be completely independent of the RAS system. However, taken together the above studies demonstrate that renal PRR plays a prominent pathophysiological role in renal dysfunction and inflammation.

\section{Summary}

In conclusion, the studies have demonstrated that PRR plays a significant role in the development of renal dysfunction, inflammation, and fibrosis. While the association between PRR and the inflammatory process is complex. These findings identify PRR as a potential therapeutic target in the management of renal complications in pathological disease.

\section{Author Contributions}

All authors made substantial contributions to conception and design, acquisition of data, or analysis and interpretation of data; took part in drafting the article or revising it critically for important intellectual content; agreed to submit to the current journal; gave final approval of the version to be published; and agree to be accountable for all aspects of the work.

\section{Disclosure}

The authors report no conflicts of interest in this work.

\section{References}

1. Re RN. Intracellular renin and the nature of intracrine enzymes. Hypertension. 2003;42(2):117-122. doi:10.1161/01.HYP.0000082495. 93495.5B

2. Nguyen G, Delarue F, Burckle C, Bouzhir L, Giller T, Sraer JD. Pivotal role of the renin/prorenin receptor in angiotensin II production and cellular responses to renin. $J$ Clin Invest. 2002;109 (11):1417-1427. doi:10.1172/JCI0214276

3. Quadri S, Siragy HM. (Pro)renin receptor contributes to regulation of renal epithelial sodium channel. J Hypertens. 2016;34(3):486-94; discussion 494. doi:10.1097/HJH.0000000000000825

4. Quadri SS, Culver S, Ramkumar N, Kohan DE, Siragy HM. (Pro) Renin receptor mediates obesity-induced antinatriuresis and elevated blood pressure via upregulation of the renal epithelial sodium channel. PLoS One. 2018;13(8):e0202419. doi:10.1371/journal.pone.0202419

5. Quadri SS, Culver S, Siragy HM. Prorenin receptor mediates inflammation in renal ischemia. Clin Exp Pharmacol Physiol. 2018;45 (2):133-139. doi:10.1111/1440-1681.12868

6. Prieto MC, Botros FT, Kavanagh K, Navar LG. Prorenin receptor in distal nephron segments of 2-kidney, 1-clip goldblatt hypertensive rats. Ochsner J. 2013;13(1):26-32. 
7. Quadri S, Siragy HM. Regulation of (pro)renin receptor expression in mIMCD via the GSK-3beta-NFAT5-SIRT-1 signaling pathway. Am J Physiol Renal Physiol. 2014;307(5):F593-F600. doi:10.1152/ ajprenal.00245.2014

8. Nguyen G, Burckle CA, Sraer JD. Renin/prorenin-receptor biochemistry and functional significance. Curr Hypertens Rep. 2004;6 (2):129-132. doi:10.1007/s11906-004-0088-3

9. Gatineau E, Gong MC, Yiannikouris F. Soluble prorenin receptor increases blood pressure in high fat-fed male mice. Hypertension. 2019;74(4):1014-1020. doi:10.1161/ HYPERTENSIONAHA.119.12906

10. Cousin C, Bracquart D, Contrepas A, Corvol P, Muller L, Nguyen G. Soluble form of the (pro)renin receptor generated by intracellular cleavage by furin is secreted in plasma. Hypertension. 2009;53 (6):1077-1082. doi:10.1161/HYPERTENSIONAHA.108.127258

11. Lu X, Wang F, Xu C, et al. Soluble (pro)renin receptor via beta-catenin enhances urine concentration capability as a target of liver X receptor. Proc Natl Acad Sci U S A. 2016;113(13):E1898E1906. doi:10.1073/pnas.1602397113

12. Ludwig J, Kerscher S, Brandt U, et al. Identification and characterization of a novel $9.2-\mathrm{kDa}$ membrane sector-associated protein of vacuolar proton-ATPase from chromaffin granules. J Biol Chem. 1998;273(18):10939-10947. doi:10.1074/jbc.273.18.10939

13. Lu X, Garrelds IM, Wagner CA, Danser AH, Meima ME. (Pro)renin receptor is require for prorenin-dependent and -independent regulation of vacuolar $\mathrm{H}(+)$-ATPase activity in MDCK.C11 collecting duct cells. Am J Physiol Renal Physiol. 2013;305(3):F417-F425. doi:10.1152/ajprenal.00037.2013

14. Cruciat CM, Ohkawara B, Acebron SP, et al. Requirement of prorenin receptor and vacuolar H+-ATPase-mediated acidification for Wnt signaling. Science. 2010;327(5964):459-463. doi:10.1126/ science. 1179802

15. Kinouchi K, Ichihara A, Itoh H. Functional characterization of (pro) renin receptor in association with V-ATPase. Front Biosci (Landmark Ed). 2011;16:3216-3223. doi:10.2741/3907

16. Oshima Y, Kinouchi K, Ichihara A, et al. Prorenin receptor is essential for normal podocyte structure and function. J Am Soc Nephrol. 2011;22(12):2203-2212. doi:10.1681/ASN.2011020202

17. Riediger F, Quack I, Qadri F, et al. Prorenin receptor is essential for podocyte autophagy and survival. J Am Soc Nephrol. 2011;22 (12):2193-2202. doi:10.1681/ASN.2011020200

18. Li C, Siragy HM. High glucose induces podocyte injury via enhanced (pro)renin receptor-Wnt-beta-catenin-snail signaling pathway. PLoS One. 2014;9(2):e89233. doi:10.1371/journal.pone.0089233

19. Chappell MC. S1P (Site-1 Protease)-induced release of the soluble prorenin receptor in hypertension: do all roads lead to Ang II (Angiotensin II)? Hypertension. 2021;77(2):417-419. doi:10.1161/ HYPERTENSIONAHA.120.16428

20. Feng Y, Peng K, Luo R, Wang F, Yang T. Site-1 protease-derived soluble (pro)renin receptor contributes to angiotensin II-induced hypertension in mice. Hypertension. 2021;77(2):405-416. doi:10.1161/HYPERTENSIONAHA.120.15100

21. Schefe JH, Neumann C, Goebel M, et al. Prorenin engages the (pro) renin receptor like renin and both ligand activities are unopposed by aliskiren. $J$ Hypertens. 2008;26(9):1787-1794. doi:10.1097/ HJH.0b013e3283060f2e

22. Feldt S, Batenburg WW, Mazak I, et al. Prorenin and renin-induced extracellular signal-regulated kinase $1 / 2$ activation in monocytes is not blocked by aliskiren or the handle-region peptide. Hypertension. 2008;51(3):682-688. doi:10.1161/ HYPERTENSIONAHA.107.101444

23. Saris JJ, t Hoen PA, Garrelds IM, et al. Prorenin induces intracellular signaling in cardiomyocytes independently of angiotensin II. Hypertension. 2006;48(4):564-571. doi:10.1161/01.HYP.00002 40064.19301.1b
24. Huang J, Siragy HM. Glucose promotes the production of interleukine-1beta and cyclooxygenase-2 in mesangial cells via enhanced (Pro)renin receptor expression. Endocrinology. 2009;150 (12):5557-5565. doi:10.1210/en.2009-0442

25. Li C, Siragy HM. (Pro)renin receptor regulates autophagy and apoptosis in podocytes exposed to high glucose. Am J Physiol Endocrinol Metab. 2015;309(3):E302-E310. doi:10.1152/ ajpendo.00603.2014

26. Huang J, Siragy HM. Regulation of (pro)renin receptor expression by glucose-induced mitogen-activated protein kinase, nuclear factor-kappaB, and activator protein-1 signaling pathways. Endocrinology. 2010;151(7):3317-3325. doi:10.1210/en.2009-1368

27. Anderson S, Rennke HG, Brenner BM. Therapeutic advantage of converting enzyme inhibitors in arresting progressive renal disease associated with systemic hypertension in the rat. J Clin Invest. 1986;77(6):1993-2000. doi:10.1172/JCI112528

28. Wang F, Lu X, Liu M, Feng Y, Zhou SF, Yang T. Renal medullary (pro)renin receptor contributes to angiotensin II-induced hypertension in rats via activation of the local renin-angiotensin system. $B M C$ Med. 2015;13:278. doi:10.1186/s12916-015-0514-1

29. Lu X, Wang F, Liu M, et al. Activation of ENaC in collecting duct cells by prorenin and its receptor PRR: involvement of Nox4-derived hydrogen peroxide. Am J Physiol Renal Physiol. 2016;310(11): F1243-F1250. doi:10.1152/ajprenal.00492.2015

30. Li W, Sullivan MN, Zhang S, et al. Intracerebroventricular infusion of the (Pro)renin receptor antagonist PRO20 attenuates deoxycorticosterone acetate-salt-induced hypertension. Hypertension. 2015;65(2):352-361. doi:10.1161/HYPERTENSIONAHA. 114.04458

31. Ramkumar N, Kohan DE. Role of the collecting duct renin angiotensin system in regulation of blood pressure and renal function. Curr Hypertens Rep. 2016;18(4):29. doi:10.1007/s11906-016-0638-5

32. Gonzalez AA, Lara LS, Luffman C, Seth DM, Prieto MC. Soluble form of the (pro)renin receptor is augmented in the collecting duct and urine of chronic angiotensin II-dependent hypertensive rats. Hypertension. 2011;57(4):859-864. doi:10.1161/HYPERTENSI ONAHA.110.167957

33. Ramkumar N, Stuart D, Calquin M, et al. Nephron-specific deletion of the prorenin receptor causes a urine concentration defect. Am J Physiol Renal Physiol. 2015;309(1):F48-F56. doi:10.1152/ ajprenal.00126.2015

34. Kaneshiro Y, Ichihara A, Sakoda M, et al. Slowly progressive, angiotensin II-independent glomerulosclerosis in human (pro)renin receptor-transgenic rats. J Am Soc Nephrol. 2007;18(6):1789-1795. doi:10.1681/ASN.2006091062

35. Huang Y, Wongamorntham S, Kasting J, et al. Renin increases mesangial cell transforming growth factor-betal and matrix proteins through receptor-mediated, angiotensin II-independent mechanisms. Kidney Int. 2006;69(1):105-113. doi:10.1038/sj.ki.5000011

36. Cheng J, Diaz Encarnacion MM, Warner GM, Gray CE, Nath KA, Grande JP. TGF-beta1 stimulates monocyte chemoattractant protein-1 expression in mesangial cells through a phosphodiesterase isoenzyme 4-dependent process. Am J Physiol Cell Physiol. 2005;289(4):C959C970. doi:10.1152/ajpcell.00153.2005

37. National Kidney Foundation. KDOQI clinical practice guidelines and clinical practice recommendations for diabetes and chronic kidney disease. Am J Kidney Dis. 2007;49(2 Suppl 2):112-154. doi:10.1053/ j.ajkd.2006.12.005

38. Carey RM, Siragy HM. The intrarenal renin-angiotensin system and diabetic nephropathy. Trends Endocrinol Metab. 2003;14 (6):274-281. doi:10.1016/S1043-2760(03)00111-5

39. Matavelli LC, Huang J, Siragy HM. (Pro)renin receptor contributes to diabetic nephropathy by enhancing renal inflammation. Clin Exp Pharmacol Physiol. 2010;37(3):277-282. doi:10.1111/j.14401681.2009.05292.x 
40. Lewis EJ, Hunsicker LG, Bain RP, Rohde RD. The effect of angiotensin-converting-enzyme inhibition on diabetic nephropathy. The Collaborative Study Group. $N$ Engl J Med. 1993;329 (20):1456-1462. doi:10.1056/NEJM199311113292004

41. Brenner BM, Cooper ME, de Zeeuw D, et al. Effects of losartan on renal and cardiovascular outcomes in patients with type 2 diabetes and nephropathy. N Engl J Med. 2001;345(12):861-869. doi:10.1056/ NEJMoa011161

42. Siragy HM, Huang J. Renal (pro)renin receptor upregulation in diabetic rats through enhanced angiotensin AT1 receptor and NADPH oxidase activity. Exp Physiol. 2008;93(5):709-714. doi:10.1113/expphysiol.2007.040550

43. Miller JA, Floras JS, Zinman B, Skorecki KL, Logan AG. Effect of hyperglycaemia on arterial pressure, plasma renin activity and renal function in early diabetes. Clin Sci (Lond). 1996;90(3):189-195. doi:10.1042/cs0900189

44. Luetscher JA, Kraemer FB, Wilson DM, Schwartz HC, Bryer-Ash M. Increased plasma inactive renin in diabetes mellitus. A marker of microvascular complications. $N$ Engl J Med. 1985;312 (22):1412-1417. doi:10.1056/NEJM198505303122202

45. Li Z, Zhou L, Wang Y, et al. (Pro)renin receptor is an amplifier of wnt/beta-catenin signaling in kidney injury and fibrosis. J Am Soc Nephrol. 2017;28(8):2393-2408. doi:10.1681/ASN.2016070811

46. Ichihara A, Suzuki F, Nakagawa T, et al. Prorenin receptor blockade inhibits development of glomerulosclerosis in diabetic angiotensin II type 1a receptor-deficient mice. J Am Soc Nephrol. 2006;17 (7):1950-1961. doi:10.1681/ASN.2006010029

47. Ichihara A, Hayashi M, Kaneshiro Y, et al. Inhibition of diabetic nephropathy by a decoy peptide corresponding to the "handle" region for nonproteolytic activation of prorenin. J Clin Invest. 2004;114 (8):1128-1135. doi:10.1172/JCI21398

48. Takahashi H, Ichihara A, Kaneshiro Y, et al. Regression of nephropathy developed in diabetes by (Pro)renin receptor blockade. $\mathrm{J} \mathrm{Am}$ Soc Nephrol. 2007;18(7):2054-2061. doi:10.1681/ASN.2006080820

49. Ortiz A, Bustos C, Alonso J, et al. Involvement of tumor necrosis factor-alpha in the pathogenesis of experimental and human glomerulonephritis. Adv Nephrol Necker Hosp. 1995;24:53-77.

50. Laster SM, Wood JG, Gooding LR. Tumor necrosis factor can induce both apoptic and necrotic forms of cell lysis. J Immunol. 1988;141 (8):2629-2634.

51. Boyle JJ, Weissberg PL, Bennett MR. Tumor necrosis factor-alpha promotes macrophage-induced vascular smooth muscle cell apoptosis by direct and autocrine mechanisms. Arterioscler Thromb Vasc Biol. 2003;23(9):1553-1558. doi:10.1161/01.ATV.0000086961.44581.B7

52. Wojciak-Stothard B, Entwistle A, Garg R, Ridley AJ. Regulation of TNF-alpha-induced reorganization of the actin cytoskeleton and cell-cell junctions by Rho, Rac, and $\mathrm{Cdc} 42$ in human endothelial cells. J Cell Physiol. 1998;176(1):150-165. doi:10.1002/(SICI) 1097-4652(199807)176:1<150::AID-JCP17>3.0.CO;2-B
53. Cheng H, Fan X, Moeckel GW, Harris RC. Podocyte COX-2 exacerbates diabetic nephropathy by increasing podocyte (pro)renin receptor expression. $J$ Am Soc Nephrol. 2011;22(7):1240-1251. doi:10.1681/ASN.2010111149

54. Suzuki-Nakagawa C, Nishimura M, Noda M, et al. Intracellular retention of the extracellular domain of the (pro)renin receptor in mammalian cells. Biosci Biotechnol Biochem. 2014;78 (7):1187-1190. doi:10.1080/09168451.2014.915732

55. Gong L, Zhang S, Li L, et al. Elevated plasma soluble (pro)renin receptor levels are associated with left ventricular remodeling and renal function in chronic heart failure patients with reduced ejection fraction. Peptides. 2019;111:152-157. doi:10.1016/j.peptides. 2018.04.010

56. Yang KT, Yang T, Symons JD. Soluble (pro)renin receptor as a potential therapy for diabetes insipidus. Am $J$ Physiol Renal Physiol. 2018;315(5):F1416-F1421. doi:10.1152/ajprenal. 00266.2018

57. Wang F, Luo R, Peng K, et al. Soluble (pro)renin receptor regulation of $\mathrm{ENaC}$ involved in aldosterone signaling in cultured collecting duct cells. Am J Physiol Renal Physiol. 2020;318(3):F817-F825. doi:10.1152/ajprenal.00436.2019

58. Peng K, Lu X, Wang F, et al. Collecting duct (pro)renin receptor targets $\mathrm{ENaC}$ to mediate angiotensin II-induced hypertension. $\mathrm{Am}$ J Physiol Renal Physiol. 2017;312(2):F245-F253. doi:10.1152/ ajprenal.00178.2016

59. Fu Z, Hu J, Wang F, et al. A5703 the soluble (Pro)renin receptor induces endothelial cell dysfunction by activating the Nox $4 / \mathrm{NF}-\kappa \mathrm{B}$ pathway. $J$ Hypertens. 2018;36:e36. doi:10.1097/01. hjh.0000548132.54349.c5

60. Wang F, Luo R, Zou CJ, et al. Soluble (pro)renin receptor treats metabolic syndrome in mice with diet-induced obesity via interaction with PPARgamma. JCI Insight. 2020;5(7). doi:10.1172/jci. insight.128061.

61. Xie S, Su J, Lu A, et al. Soluble (pro)renin receptor promotes the fibrotic response in renal proximal tubule epithelial cells in vitro via the Akt/beta-catenin/Snail signaling pathway. Am J Physiol Renal Physiol. 2020;319(5):F941-F953. doi:10.1152/ajprenal.00197.2020

62. Seravalle G, Grassi G. Sympathetic nervous system, hypertension, obesity and metabolic syndrome. High Blood Press Cardiovasc Prev. 2016;23(3):175-179. doi:10.1007/s40292-016-0137-4

63. Gamboa A, Figueroa R, Paranjape SY, Farley G, Diedrich A, Biaggioni I. Autonomic blockade reverses endothelial dysfunction in obesity-associated hypertension. Hypertension. 2016;68 (4):1004-1010. doi:10.1161/HYPERTENSIONAHA.116.07681

64. Rahmouni K. Leptin-induced sympathetic nerve activation: signaling mechanisms and cardiovascular consequences in obesity. Curr Hypertens Rev. 2010;6(2):104-209. doi:10.2174/ 157340210791170994
Journal of Experimental Pharmacology

\section{Publish your work in this journal}

The Journal of Experimental Pharmacology is an international, peerreviewed, open access journal publishing original research, reports, reviews and commentaries on all areas of laboratory and experimental pharmacology. The manuscript management system is completely online and includes a very quick and fair peer-review system. Visit http://www.dovepress.com/testimonials.php to read real quotes from published authors. 